Journal of Development and Communication Studies, Vol. 8. No. 1, January -June, 2021 ISSN (Online \& Print): 2305-7432. http://www.devcomsjournalmw.org

\title{
Determinants of Cellphone Usage among Sea Fisher's During Marine Fishing in Selected Coastal Villages of Bangladesh
}

\author{
Md. Salahuddin Ahmed, Md. Mamun-ur-Rashid \& Md. Tareq Mahmood. Email: \\ murashid@pstu.ac.bd, Department of Agricultural Extension and Rural Development, Patuakhali \\ Science and Technology University,
}

\begin{abstract}
The cell phone can provide numerous benefits to sea fishers who risk their lives and resources for making livelihoods. This article is based on the firm assumption that the use of the cell phone during marine fishing can contribute to income, security and risk reduction. This study adds to the empirical evidence of determinants of cell phone use by fishers during marine fishing. For the purpose of reaching objectives, the study has drawn quantitative data generated through structured face-to-face interviews with 200 randomly selected fishers from three selected villages adjacent to the Bay of Bengal in the mid coastal area of Bangladesh during the period January to February 2016. Descriptive statistics, inferential statistics and binary logistic regression model is used to analyze the data. The study concludes that fishers own cell phone (odds ratio[OR] $=6.56$, 95 per cent confidence interval $[\mathrm{CI}]: 1.69,25.44)$, enjoying the availability of cell phone network (OR=166.20, 95 per cent CI:38.35, 720.28), earned low $(\mathrm{OR}=20.35,95$ per cent $\mathrm{CI}: 4.24,97.28)$ to medium income (OR=9.53, 95 per cent CI:0.99, 91.12) form sea fishing have a greater tendency to use cell phones, while fishers had low information need (OR=0.11, 95 per cent CI:0.01, 1.13) represented lower use of cell phone during marine fishing. Thus, it is essential to build cell phone infrastructure bases in the potential fishing zones of Bangladesh and supplying cell phone devices at subsidised cost.
\end{abstract}

Keywords: Sea fishers; Cell phone; Use; Determinants; Bangladesh

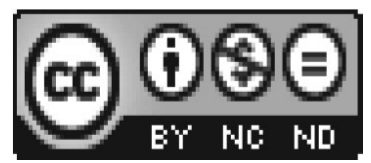

(c) 2020. The authors. This work is licensed under the Creative Commons Attribution 4.0 International License (CC-By-NC-ND). Users may freely share and redistribute this work provided that the author and the Journal of Development and Communication Studies are fully acknowledged. Users may not tweak or remix and offer this work for sale. The full license may be accessed at https://creativecommons.org/licenses/by-nc-nd/4.0/ 
To cite this article: Md. Salahuddin, A., Md. Mamun-ur-Rashid $\mathcal{E}$ Md. Tareq, A. . (2021). Determinants of Cellphone Usage among Sea Fisher's During Marine Fishing in Selected Coastal Villages of Bangladesh, Journal of Development and Communication Studies, 8(1), 125 - 143

https://dx.doi.org/10.4314/jdcs.v8i1.6

\section{Introduction}

The marine fisheries sector is considered as an important sector of the economy of Bangladesh (Hussain and Haque, 2010). The Bay of Bengal is one of the world's 64 Large Marine Ecosystem (LMEs), and eventually the sea water of Bangladesh is endowed with 475 species of fishes, 36 species of shrimps, 5 species of lobsters, more than 15 species of crabs, 5 species of tortoise, and 15 species of coral. In 2014-2015, $16.28 \%$ of the total produced fish in the country came from sea fisheries sector (Humayan \& Barua, 2016). Not only fish production, this sector also offers livelihood for a significant section of people in the country. For instance, about one million people are securing their earning through marine fishing (Khan, 2010).

Natural hazards and technological failure have turned sea fishing to a risky profession since a long period of time (Smith, 1998). Sea fishers encountered several occupational hazards, such as accidents during hauling in nets (Lincoln, 2002), health risk from diseases (Kissling et al., 2005), substantial variability in catch, which contributed to financial uncertainty in return (Salas et al., 2011). Frequent occurrence of tropical cyclone in Bangladesh is making sea water progressively rougher (Nishikura, 2010). Incidence of frequent pirate attack is a recent addition to the risks of sea fishing, cost sizeable amount of lives and resources (Rider, 2015; Financial Express, 2016; Pandey, 2015).

Information becomes the most crucial commodity during emergencies and disaster incidents (Barrantes et al., 2009; FEMA, 2014). Media and communication can play pivotal role in saving lives of people vulnerable to disaster. It can assist people in changing attitude towards risks and encouraging action towards resilience building. Therefore, most emergency agencies around the globe use social media alongside traditional media (e.g. television, newspaper, community meetings, etc.) to communicate for warning, response, and recovery (Dufty, 2014). Fish friend, a mobile application in India, is offering comprehensive information on ocean condition such as wind speed, wind direction and weave height along with early warning information on disaster like cyclones, high waves, heavy rainfall, etc. This information helps fishermen to decide whether it is safe to go or not to the ocean and which type of fishing gear to take with them (Qualicomm, 2016). A localised mobile based alert service, such as weather forecast, when and where to fish in Lake Victoria played 
crucial role to secure lives and preserves livelihood of the fishers in Uganda (Erricson, 2012).

Cell phone due to its potentials in supporting two-way communication and access to rich information sources, such as the internet can be a potential way of offering information to the sea fishers of Bangladesh. Cellphone can make sea fishing enjoyable and easier (Amrita \& Karthickumar, 2016). However, adoption of cell phone depends upon numerous factors, such as market, household, and social factors (Obong, Mugonola \& Phillips, 2017). In case marine fishing, the factors of cell phone use remain blurred due to the paucity of research. Hence, it is essential to identify the determinants of cell phone use during marine fishing to assist stakeholders' devise effective strategies to address the issues limiting the use of cellphone during marine fishing in Bangladesh.

\section{Objectives of the study}

The main objective of this study was to reveal the determinants of sea fisher use of cellphone during marine fishing. However, the specific objectives of the study were as follows:

I. To reveal the present status of the network availability, ownership, and use of cellphone by the sea fishers during marine fishing.

II. To determine the factors affecting the use of cellphone by the sea fishers during marine fishing.

\section{Methodology}

\section{Research framework and hypothesis}

A Mobile phone can facilitate faster and cheaper two-way communication, which can improve the life of the sea fishermen through better income and reduction of risks. Hence, the usage of mobile application in fisheries sector in developing countries is gaining popularity (Amirta \& Karthickumar, 2016). Mobile technology can enhance income and easy access to market. Jensen (2007) in a study in Kerala, India found that due to coverage of cell phone fisherman's travel from their usual markets soar from $0 \%$ to $35 \%$. During emergencies, such as engine failure in the deep sea, fishermen can acquire precise information on how to repair engine (Govindaraju \& Mabel, 2010) and can keep in touch with family members until return to their residence (Boadi et al., 2007). According to Amirta \& Karthickumar (2016) mobile applications serve as various valuable tools, such as solunar, tidal charts, advance weather reporting, radar maps, forecast and incidental reporting, GPS advance tracking, Catch Log Book, sea depth measuring, and tracking of potential fishing zone. However, the decision to use cell phone is likely to depend on a number of factors which can be grossly classified into personal, socioeconomic and situational factors. 
Among the personal factors age, education level, etc., can influence cell phone use in communicating agricultural information (Nymba \& Mlozi, 2012). Alam et al. (2018) and Obong, Mugonola and Phillips (2017) in their studies in Bangladesh and Uganda identified age and education as a significant determinant of cell phone adoption and use. However, all these studies were in consensus that the use of cellphone decrease with the increase of age. Contradicting this finding Olumide et al. (2010) in Mathuha (2015) found that the age along with education significantly influence an older person's attitude toward perceived usefulness and perceived ease of use of cellphone. Family size can also influence the adoption of technology, as large family has more demand of economic benefit. Moreover, large household need more information exchange, which may influence cellphone use. Thus, Akinola (2017) and Njuguna et al. (2015) in their studies found family size as a significant determinant of cell phone use and adoption. Use of cell phone can also be influenced by marital status. Actually, single and married people have different context, tendencies and information need. In a study in Iraq, Altabatabaie (2018) found that use of cell phone significant vary with marital status and single people showed significantly more use of cell phone compared to married people. Farming experience is another factor can contribute negatively to cell phone use as people having high experience in their job often remain reluctant in using other information sources for better performance. Hence, Asif et al. (2017) in their study found reverse association between farming experience and use of cell phone. Therefore, this research deserved to reveal the impact of personal factors in cell phone use during marine fishing.

H1: Age has an impact on marine fishers' use of cell phone during marine fishing H2: Education has an impact on marine fishers' use of cell phone during marine fishing H3: Family size has an impact on marine fishers' use of cell phone during marine fishing H4: Marital status has an impact on marine fishers' use of cell phone during marine fishing H5: Fishing experience has an impact on marine fishers' use of cell phone during marine fishing

Among the socio-economic factors income has been identified as a crucial determinant of cell phone use in several numbers of studies (Alam et al., 2018; Obong, Mugonola and Phillips, 2017; Nymba \& Mlozi, 2012). Ownership very often ensures instant access to cell phone when accompanied by adequate skill. Thus, Okello et al. (2014) in his study identified mobile phone ownership as a significant determinant of ICT use in Kenya. Nymba \& Mlozi (2012) also revealed ownership as an important factor shaping the use of cell phone for agricultural information. Hence, this research also perceives that socioeconomic factors can significantly contribute to use of cellphone during marine fishing. 
H6: Income of sea fishers' can significantly influence the use of cell phone during marine fishing

H7: Ownership of cell phone can significantly influence the use of cell phone during marine fishing

Information need and facilities required for operating the technology can play crucial role in shaping the usage of technology. Among the situational factors Nymba \& Mlozi (2012) identified agricultural information need as a decisive factor influencing the use of cell phone in acquiring agricultural information. Network availability has been identified as one of the important conditions in cell phone and/or ICT use in several studies conducted in varied geographical locations (Urassa and Mvena, 2016; Tirkaso and Hess, 2015; Mathuha, 2015; Nymba \& Mlozi, 2012;). Therefore, this research is profoundly interested in exploring the effect of situational factors in cell phone use during marine fishing and presented the research framework diagrammatically in Figure 1.

H8: Information need can significantly contribute to the use of cell phone during marine fishing

H9: Cell phone network availability can significantly influence the use of cell phone during marine fishing

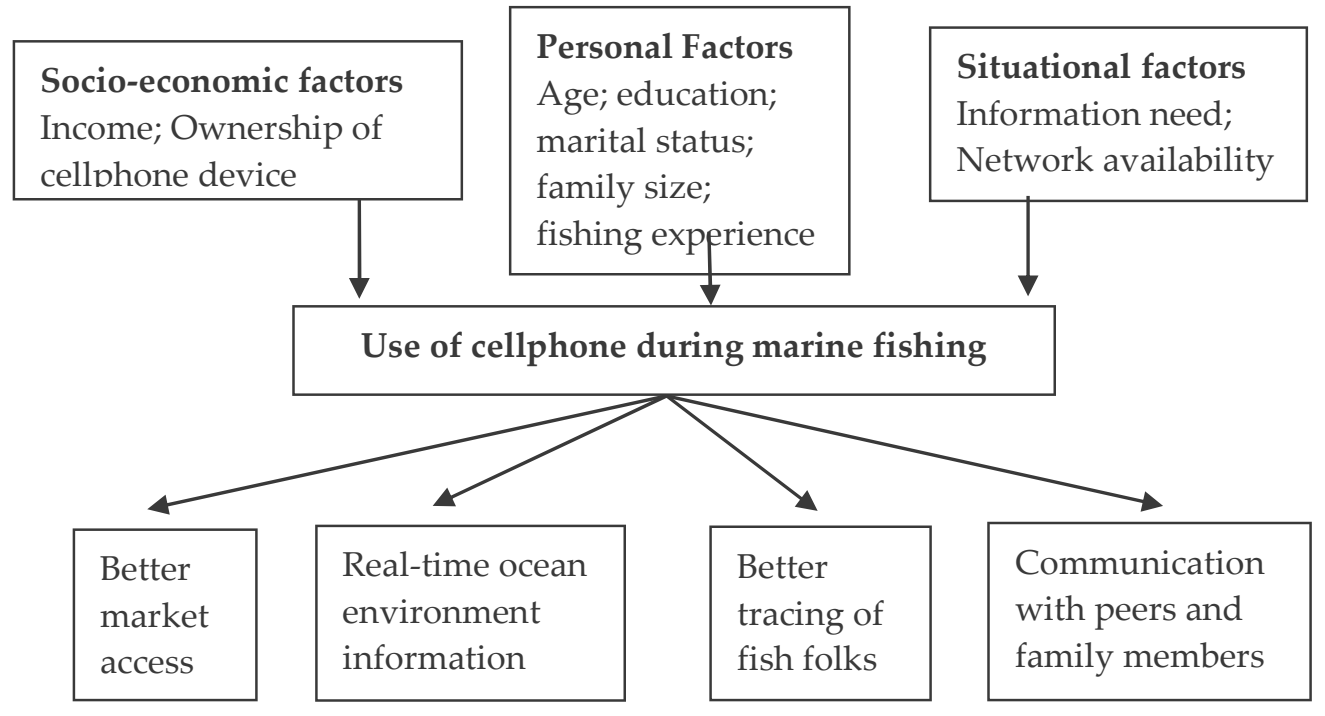

Fig.1 Research framework

\section{Study site}


This study was conducted in three selected coastal villages of Patharghata Upazila under Barguna district. The names of the selected villages were Padma, Ruhita, and Badurtala under Patharghata Sadar Union. Patharghata Upazila is mainly bounded by the Bay of Bengal on the southern side, the Biskhali and Baleswar Rivers on the eastern and western sides. The study area is renowned for the presence of a large number of fishermen directly involved in marine fishing. The total area of this upazila is 387.36 Square $\mathrm{km}$ and population is about 1, 63,927 (BBS, 2011). This study area has lots of riverine area hence a huge amount of marine fisheries resources is collected every year. However, a map of the study area is displayed in Figure 2.

Figure 2: Map of the study area

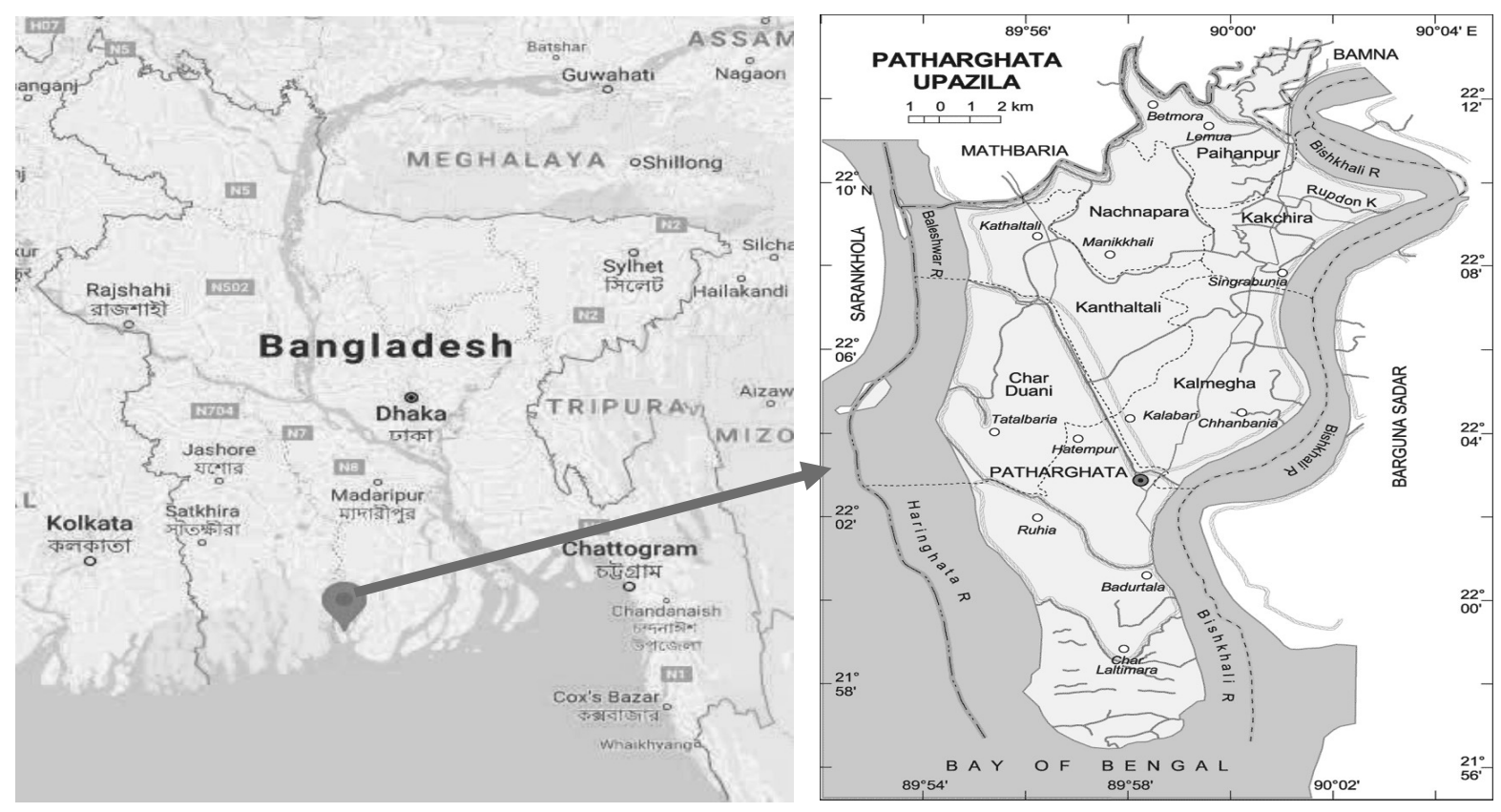




\section{Study design}

This study adopted structured interview elicited response pertaining to sea fisher's demographic characteristics and use of cellphone during marine fishing as well as their information need, cellphone ownership and network availability.

\section{Population sampling}

All the fisheries of three selected villages, fish regularly in the ocean were the population of the study. At first, a list of all the sea fishers were prepared, which included 675 individuals. Consequently, a random sampling method was used to determine the sample size. It is noteworthy to mention that at $90 \%$ confidence interval and $5 \%$ margin of error the required sample size was 195 . Hence, this study selected 202 sea fishers for interview. It is important to note that during final analysis two respondents were dropped due to inconsistency in given information. Therefore, the sample size considered during final analysis was 200.

\section{Measurement of Variables}

Use of cellphone during marine fishing was the criterion variable of the study and was measured based on dichotomous response, such as yes and no. The respondents used cellphone 2-3 times in last one month during marine fishing were considered as the user of cellphone, while the participants who did not use cellphone at least 2 times in last one month during marine fishing was identified as non-user of cellphone. However, a detail of the hypothesised variables of this study, their definition and measurement are displayed in Table 1.

Table 1: Hypothesised variables of the study

\begin{tabular}{|l|l|l|l|l|}
\hline Variables & Explanation & Type & Measurement & Value \\
\hline UCELL & $\begin{array}{l}\text { Use of cellphone during } \\
\text { marine fishing }\end{array}$ & Dummy & $\begin{array}{l}\text { Yes (use cellphone at } \\
\text { least 2-3 } \\
\text { times/month) } \\
\text { No (Don't use } \\
\text { cellphone in last one } \\
\text { month) }\end{array}$ & \\
\hline AGE & Age of the respondents & Continuous & $\begin{array}{l}\text { Score } 1 \text { for each } \\
\text { completed }\end{array}$ & $+/-$ \\
\hline
\end{tabular}




\begin{tabular}{|c|c|c|c|c|}
\hline EDU & $\begin{array}{l}\text { Education of the } \\
\text { respondents }\end{array}$ & Dummy & $\begin{array}{l}\text { Can't read and } \\
\text { write }=0 ; \text { Can read } \\
\text { and write }=1\end{array}$ & + \\
\hline MARST & $\begin{array}{l}\text { Marital status of the } \\
\text { respondents }\end{array}$ & Dummy & $\begin{array}{l}1=\text { Married; } 0= \\
\text { Unmarried }\end{array}$ & $+/-$ \\
\hline FAMSZ & $\begin{array}{l}\text { Family size of the } \\
\text { respondents }\end{array}$ & Continuous & $\begin{array}{l}\text { Number of } \\
\text { individuals /family }\end{array}$ & $+/-$ \\
\hline EXPFISH & $\begin{array}{l}\text { Experience in marine } \\
\text { fishing }\end{array}$ & Continuous & $\begin{array}{l}\text { Score } 1 \text { for each year } \\
\text { of experience }\end{array}$ & $+/-$ \\
\hline INCFISH & Income from sea fishing & Continuous & Score 1 for each '000' & + \\
\hline INFNED & $\begin{array}{l}\text { Information need } \\
\text { during marine fishing }\end{array}$ & Continuous & $\begin{array}{l}\text { Score }(\text { Regularly }=4 \text {, } \\
\text { Frequently }=3, \\
\text { Occasionally=2, } \\
\text { Rarely }=1, \mathrm{No}=0) \\
\text { against } 7 \text { items }\end{array}$ & + \\
\hline AVCENT & $\begin{array}{l}\text { Availability of } \\
\text { cellphone network } \\
\text { during marine fishing }\end{array}$ & Dummy & Yes $=1 ; \mathrm{No}=0$ & + \\
\hline OWCELL & $\begin{array}{l}\text { Personal ownership of } \\
\text { cellphone by the } \\
\text { respondent }\end{array}$ & Dummy & Own=1; Don't own $=0$ & + \\
\hline
\end{tabular}

\section{Statistical analysis}

For describing general characteristics of the respondents this study used descriptive statistics, such as weighted mean, frequency, percentage, etc. The association between predictors and criterion variable was explored deploying chi-square test. Finally, to reveal the determinants of cellphone use during marine fishing, this study adopted logistic regression analysis. In this research, the use of cellphone during marine fishing could take a value of 1 if used and o otherwise. As described by Gugrati, Porter, \& Gunasekar (2012), the functional form of logistic model is:

$$
\begin{aligned}
& P_{i}=E\left(Y=\frac{f}{x}\right)=1 \\
& P_{i}=E\left(Y=\frac{1}{x}\right)=\frac{1}{\left.1+e^{-\left(\beta_{0}+\beta_{1} x_{1} \ldots \ldots\right.} \beta_{n} x_{n}\right)}
\end{aligned}
$$

For ease of exposition, we can write equation (2) as

$$
P_{i}=\frac{1}{1+e^{Z_{i}}}
$$

If $\mathrm{P}_{\mathrm{i}}$ the probability of using cellphone in equation (3) then (1- $\left.\mathrm{P}_{\mathrm{i}}\right)$, the probability of not using cellphone, is

$$
1-P_{i}=\frac{1}{1+e^{Z_{i}}}
$$


Therefore, we can write

$\frac{P_{i}}{1-P_{i}}=\frac{1+e^{Z_{i}}}{1+e^{-Z_{i}}}$

Now $P_{\mathrm{i}} /\left(1-P_{\mathrm{i}}\right)$ is simply the odds ratio in favor of using cellphone - the ratio of the probability that a person will use cellphone to the probability that the person will not use cellphone.

Now if we take the natural log of equation (5) we obtain

$L_{i}=\ln \left(\frac{P_{i}}{1-P_{i}}\right)=Z_{i}=\beta_{0}+\beta_{1} X_{1}+\beta_{2} X_{i}+\beta_{n} X_{n}$

$Z_{\mathrm{i}}=$ is the function of explanatory variables $(\mathrm{x})$ which is also expressed as:

$Z_{i}=\beta_{0}+\beta_{1} X_{1}+\beta_{2} X_{i}+\beta_{n} X_{n}$

$\beta_{0}=$ Incept

$\beta_{1}, \beta_{2} \ldots \ldots . . . \beta_{n}$ are the slopes of equation in the model

$X_{i}=$ in the vector of relevant determinant

$Z_{i}=$ is the $\log$ of odds ratio

If the stochastic error term $u_{i}$ is introduced, the logit model stands as:

$Z_{i}=\beta_{0}+\beta_{1} X_{1}+\beta_{2} X_{i}+\beta_{n} X_{n}+u_{i}$

Before the development of the final model Multicollinearity among the independent variables was assessed and Variance Inflation Factors (VIF) was used to determine the association among independent variables. It is noteworthy to mention that all the analyses were performed using IBM SPSS statistics 23 software.

\section{Results and Discussions}

\section{Description and association of sociodemographic characteristics with cell phone use}

The majority of the respondents $(61.50 \%)$ was old young and can read and write $(81.50 \%)$, and almost all of them $(98.50 \%)$ were married. Most of the respondents $(74.50 \%)$ belonged to medium size family and had moderate $(70 \%)$ fishing experience. More than two third $(79.50 \%)$ of the respondents had low to moderate income from marine fishing and had medium (69.50\%) information need. In case of availability of cell phone network, less than one third respondents (30.50\%) explained the cell phone network as available and almost similar percentage $(28.50 \%)$ of the respondents own cell phone. A detail of all the independent predictors is displayed in Table 2. In addition, Table 2 also presents the relationship between the participant's use of cellphone and the independent predictors based on chi-square test. Characteristics such as education $(p<0.05)$, family size $(p<0.000)$, income from sea fishing $(p<0.000)$, information need $(p<0.01)$, availability of cellphone network $(p<0.000)$ and ownership of cell phone $(p<0.003)$ were significantly associated with the fisher's use of cell phone during marine fishing. 
Table 2. Association between sociodemographic variables and the use of cellphone $(n=200)$

\begin{tabular}{|c|c|c|c|c|}
\hline \multirow[t]{2}{*}{ Characteristics } & \multicolumn{3}{|c|}{ Use of cellphone } & \multirow[t]{2}{*}{$\lambda^{2}$} \\
\hline & No, n (\%) & Yes, n (\%) & $\begin{array}{l}\text { Total, } \mathrm{n} \\
(\%)\end{array}$ & \\
\hline \multicolumn{5}{|l|}{ Age } \\
\hline Young & $21(14.90)$ & $11(18.60)$ & $32(16)$ & \\
\hline Old young & $92(65.20)$ & $31(52.50)$ & $123(61.50)$ & 0.230 \\
\hline Middle aged & $28(19.90)$ & $17(28.80)$ & $45(22.50)$ & \\
\hline \multicolumn{5}{|l|}{ Education } \\
\hline Can't read or write & $32(22.70)$ & $5(8.50)$ & $37(18.50)$ & 0.018 \\
\hline Can read and write & 109 (77.30) & $54(91.50)$ & $163(81.50)$ & \\
\hline \multicolumn{5}{|l|}{ Marital status } \\
\hline Married & 139 (98.60) & $58(98.300$ & 197(98.50) & 0.883 \\
\hline Unmarried & $2(1.40)$ & $1(1.70)$ & $3(1.50)$ & \\
\hline \multicolumn{5}{|l|}{ Family size } \\
\hline Small & $99(6.40)$ & $25(42.40)$ & $34(17)$ & \\
\hline Medium & $116(82.30)$ & $33(55.90)$ & $149(74.50)$ & 0.000 \\
\hline Large & $16(11.30)$ & $1(1.70)$ & $17(8.50)$ & \\
\hline \multicolumn{5}{|l|}{ Fishing Experience } \\
\hline Low & $8(5.70)$ & $5(8.50)$ & $13(6.50)$ & \\
\hline Moderate & $101(71.60)$ & $39(66.10)$ & $140(70)$ & 0.665 \\
\hline High & $32(22.60)$ & $15(25.40)$ & $47(23.50)$ & \\
\hline \multicolumn{5}{|l|}{ Income from fishing } \\
\hline Low & $50(35.50)$ & $52(88.10)$ & $102(51)$ & \\
\hline Medium & $51(36.20)$ & $6(10.20)$ & $57(28.50)$ & 0.000 \\
\hline High & $40(28.40)$ & $1(1.70)$ & $41(20.50)$ & \\
\hline \multicolumn{5}{|l|}{ Information need } \\
\hline Low & $22(15.60)$ & $20(33.90)$ & $42(21)$ & \\
\hline Medium & $103(73)$ & $36(61)$ & $139(69.50)$ & 0.010 \\
\hline High & $16((11.30)$ & $3(5.10)$ & $19(9.50)$ & \\
\hline \multicolumn{5}{|c|}{ Availability to cellphone Network } \\
\hline No & $132(93.60)$ & $7(11.90)$ & $139(69.50)$ & 0.000 \\
\hline Yes & $9(6.40)$ & $52(88.10)$ & $61(30.50)$ & \\
\hline \multicolumn{5}{|c|}{ Ownership of cellphone } \\
\hline No & $110(78)$ & $33(55.90)$ & $143(71.50)$ & 0.003 \\
\hline Yes & $31(22)$ & $26(44.10)$ & $57(28.50)$ & \\
\hline
\end{tabular}




\section{Information need}

As indicated in Figure 2 fishers need different types of information of which need of weather information was on the top (WM=3.65). Other major aspects of information need encompass family member's information ( $\mathrm{WM}=2.54)$, fish marketing related information ( $\mathrm{WM}=2.02)$, information on places of fish availability (WM=1.55), etc. A detail of information need of sea fishers during marine fishing is presented in Figure 2. Supporting our findings, a study focused on mobile phone use in Ugandan aquaculture found that farmers used cellphone for contracting family members, input suppliers and market information (Matuha, 2015).

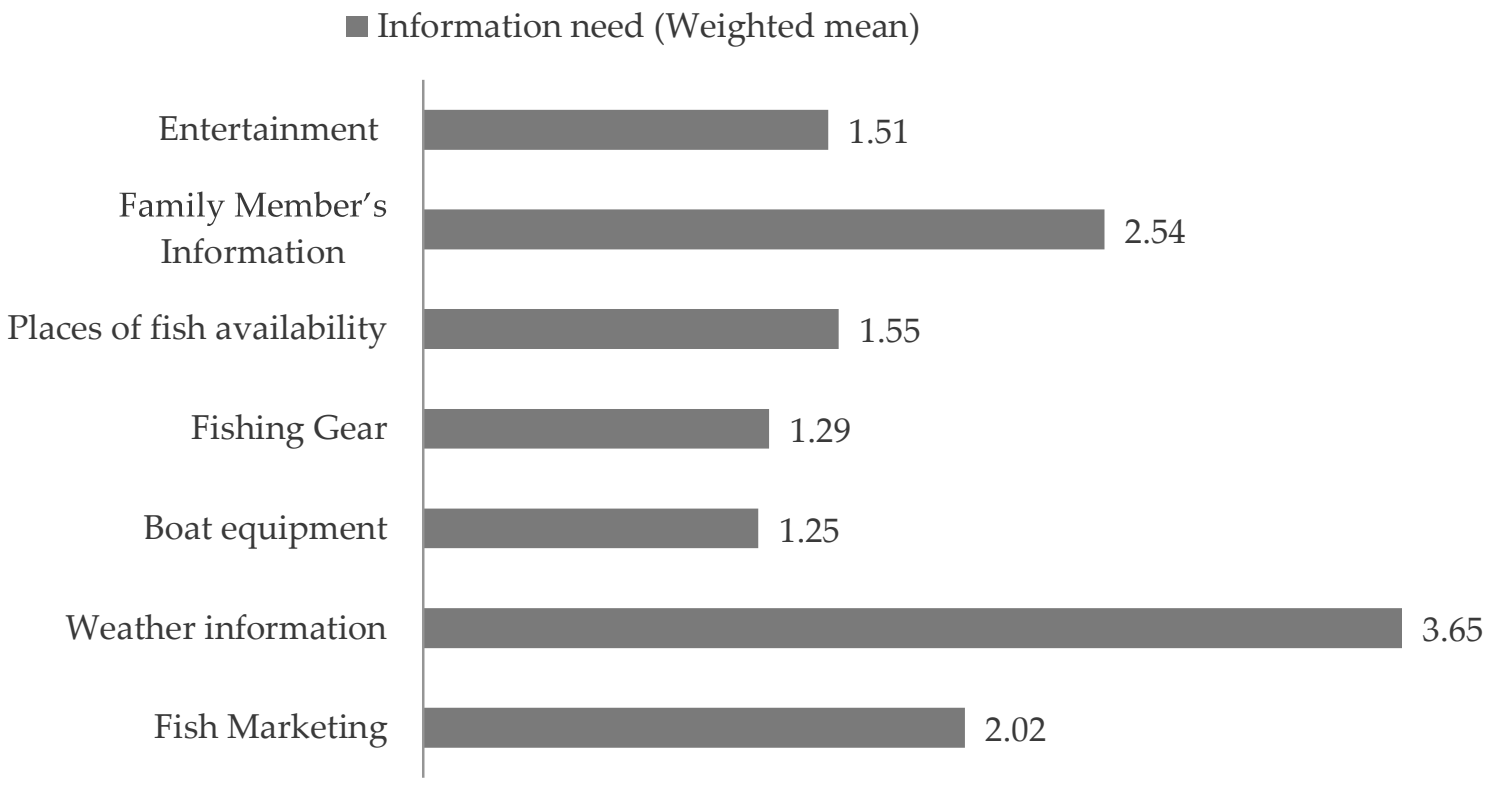

Fig.2 Information need of fishers during marine fishing

\section{Determinants of marine fisher's use of cellphone}

Table 3 presets the results of unadjusted and adjusted OR in using cell phone during marine fishing at $95 \%$ CI. Factors statistically significant in the unadjusted model were entered into the adjusted model. The findings say that among the independent predictors, income from fishing, information need, availability of cell phone network and ownership of a cell phone is significantly influencing the cell phone use. Fishers having low and medium income from sea fishing had 20.35 times $(\mathrm{OR}=20.35,95 \% \mathrm{CI}$ : 4.24, 97.48; $\mathrm{p}<0.000)$ and 9.53 times (OR=9.53, 95\% CI: 0.99, 91.12; $\mathrm{p}<0.05$ more chances to use cellphone compared to fishers having a high income. Participants having low information need are 9.09 times (Reverse $\mathrm{OR}=9.09,95 \% \mathrm{CI}$ : 0.01, 1.37; $\mathrm{p}<0.10$ ) less likely to use cellphone during marine fishing than the fishers having high information need. Fishers enjoy availability of cellphone network were 166.20 times (OR=166.20, 95\% CI: 38.35, 720.28; p<0.000) more inclined to use cellphone than those who didn't 
find mobile network available. Similarly, the participants own cell phones were 6.56 times $(\mathrm{OR}=6.56,95 \% \mathrm{CI}: 1.69,25.44 ; \mathrm{p}<0.01)$ more prone to use cellphone than the fishers didn't possess a cell phone.

Table 4. Determinants of the use of cell phone by sea fishers during marine fishing

\begin{tabular}{|c|c|c|c|c|c|c|c|c|}
\hline \multirow[t]{2}{*}{ Variable } & \multicolumn{4}{|c|}{ Unadjusted model } & \multirow{2}{*}{$\begin{array}{l}\text { Selectio } \\
\text { n for } \\
\text { adjusted } \\
\text { model }\end{array}$} & \multicolumn{3}{|c|}{ Adjusted model } \\
\hline & $\mathrm{SE}^{1}$ & $\mathrm{OR}^{2}$ & \multicolumn{2}{|c|}{$95^{\wedge} \mathrm{CI}^{3}$} & & $\mathrm{SE}^{1}$ & $\mathrm{OR}^{2}$ & $95^{\wedge} \mathrm{CI}^{3}$ \\
\hline Constant & \begin{tabular}{|l|}
4.6 \\
5 \\
\end{tabular} & 0.03 & & & & $\begin{array}{l}1.1 \\
0 \\
\end{array}$ & $0.013^{* * *}$ & \\
\hline \multicolumn{5}{|l|}{ Age } & No & & & \\
\hline Young & \begin{tabular}{|l|}
1.7 \\
2 \\
\end{tabular} & 0.13 & 0.01 & 3.63 & & & & \\
\hline $\begin{array}{l}\text { Old } \\
\text { young }\end{array}$ & $\begin{array}{l}1.2 \\
7 \\
\end{array}$ & 0.33 & 0.03 & 3.92 & & & & \\
\hline \multicolumn{2}{|c|}{$\begin{array}{l}\text { Middle aged } \\
\text { (Ref.) }\end{array}$} & 1.0 & & & & & & \\
\hline $\begin{array}{l}\text { Educatio } \\
\mathrm{n}\end{array}$ & \begin{tabular}{|l|}
1.1 \\
4 \\
\end{tabular} & 1.57 & 0.17 & 14.59 & No & & & \\
\hline $\begin{array}{l}\text { Marital } \\
\text { Status }\end{array}$ & \begin{tabular}{|l|}
4.3 \\
7
\end{tabular} & 0.59 & 0.00 & $\begin{array}{l}3101 . \\
2\end{array}$ & No & & & \\
\hline \multicolumn{5}{|c|}{ Family size } & No & & & \\
\hline Small & $\begin{array}{l}1.5 \\
7 \\
\end{array}$ & 2.05 & 0.09 & 44.17 & & & & \\
\hline Medium & \begin{tabular}{|l|}
1.5 \\
2 \\
\end{tabular} & 0.43 & 0.02 & 8.46 & & & & \\
\hline $\begin{array}{l}\text { Large } \\
\text { (Ref.) }\end{array}$ & & 1.0 & & & & & & \\
\hline \multicolumn{5}{|c|}{ Fishing Experience } & & & & \\
\hline Low & \begin{tabular}{|l|}
2.3 \\
8 \\
\end{tabular} & 3.47 & 0.03 & $\begin{array}{l}370.0 \\
3 \\
\end{array}$ & No & & & \\
\hline Medium & $\begin{array}{l}1.1 \\
8 \\
\end{array}$ & 2.39 & 0.24 & 24.03 & & & & \\
\hline $\begin{array}{l}\text { High } \\
\text { (Ref.) }\end{array}$ & & 1.0 & & & & & & \\
\hline \multicolumn{5}{|c|}{ Income from fishing } & Yes & & & \\
\hline
\end{tabular}




\begin{tabular}{|l|l|l|l|l|l|l|l|l|l|}
\hline Low & $\begin{array}{l}0.8 \\
9\end{array}$ & $21.21^{* * *}$ & 3.71 & $\begin{array}{l}121.2 \\
5\end{array}$ & & $\begin{array}{l}0.7 \\
9\end{array}$ & $20.35^{* * *}$ & 4.24 & 97.48 \\
\hline Medium & $\begin{array}{l}1.2 \\
4\end{array}$ & $10.37^{*}$ & 0.92 & $\begin{array}{l}117.1 \\
0\end{array}$ & & $\begin{array}{l}1.1 \\
5\end{array}$ & $9.53^{* *}$ & 0.99 & 91.12 \\
\hline $\begin{array}{l}\text { High } \\
\text { (Ref.) }\end{array}$ & 1.0 & & & & & 1.0 & & \\
\hline Information need & $\begin{array}{l}1.3 \\
9\end{array}$ & $0.14^{*}$ & 0.01 & 2.13 & & $\begin{array}{l}1.2 \\
0\end{array}$ & $0.11^{*}$ & 0.01 & 1.13 \\
\hline Low & $\begin{array}{l}1.2 \\
3\end{array}$ & 0.37 & 0.03 & 4.14 & & $\begin{array}{l}1.0 \\
8\end{array}$ & 0.27 & 0.03 & 2.26 \\
\hline Medium & 1.0 & & & & & & & \\
\hline $\begin{array}{l}\text { High } \\
\text { (Ref.) }\end{array}$ & $\begin{array}{l}142.92^{* *} \\
\text { AVCENT }\end{array}$ & 30.4 & $\begin{array}{l}671.4 \\
8\end{array}$ & Yes & $\begin{array}{l}0.7 \\
4\end{array}$ & $\begin{array}{l}166.20^{* *} \\
*\end{array}$ & $\begin{array}{l}38.3 \\
5\end{array}$ & 720.2 \\
\hline
\end{tabular}

Note: ${ }^{*} \mathrm{p}<0.10,{ }^{* *} \mathrm{p}<0.05$, and ${ }^{* * *} \mathrm{p}<0.01$, ${ }^{1}$ Standard Error, ${ }^{2}$ Odds ratio, ${ }^{3}$ Confidence interval, VIF = Variance Inflation Factor

A number of regression diagnostic tests were also performed to ensure the precise estimation (Table 4). The VIF value with a range of 1.02-1.33 indicated the absence of multicollinearity problem in the model (Daoud, 2017). The value of HosmerLemeshow statistics showed insignificant difference exists between the observed data and the full model $(\mathrm{p}=0.390)$, indicating a good fit between the two (Hosmer \& Lemeshow, 2000). With an area of 0.969, ROC curve confirmed the sufficient predictive power of the fitted model (Seshan, Gönen \& Beeg, 2013).

\section{Discussion}

This study aimed to examine the predictors of the use of cellphone during marine fishing in some selected villages in adjacent areas of the Bay of Bengal. The determinants that significantly increased the use of cellphone include low income from sea fishing, information need, availability of cellphone network, ownership of 
cellphone. Low income participants were most likely to use cellphone compared to high income fishers. Sikundla, Mushunje \& Akinyemi (2018) in their research focusing socioeconomic drivers of mobile phone adoption for marketing among smallholder irrigation farmers in South Africa also identified monthly income as a significant driver of mobile phone adoption. In the coastal area of Bangladesh, mobile phone network is available in the nearby areas of the shore, where the depth of the sea water is shallow and eventually has low availability of fish and other resources. On the contrary, cellphone network is not available in the deep sea, which is more resourceful compared to shallow areas. Hence, the fishers have more income from the sea fishing showed less use cell phone.

Information need during fishing has emerged as a significant determinant of cellphone use during marine fishing. Actually, marine fishers are highly vulnerable to the wilder nature of the ocean due to dynamic sea current, wind speed, direction, wave heights, etc. (Singh, Kimbhune and Singh, 2017). As a result, the fishers and their family members always remain anxious of unwanted situations. Hence, to reduce anxiety and moving to safety at the right time, real time weather information and communication with family members on shore is vital. On the other hand, getting proper price of the catch is crucial to ensure satisfactory income. Perhaps due to these facts, the major sector of information need for the fishers is weather information, family member information and fish marketing related information.

Participants enjoying availability of cellphone network were significantly highly inclined to the use of cellphone during marine fishing. Supporting our findings, Urassa \& Mvena (2016) claimed that level of cellphone network coverage had significant association with access to beef cattle market information via cellphone. Similarly, Matuha (2015) also identified cellphone network as an important factor alter the use cellphone in Ugandan aquaculture. A mobile phone is commonly described as physical device that can be carried to anywhere. It is composed of a battery to provide power and must have some type of mobile network connectivity in order for the device to operate and to send and receive data (Mobile Networking: Definition, Components \& Comparison, 2018). Therefore, the network infrastructure (e.g. available base stations) is a crucial issue to consider as it is directly linked to 'network effect' (Islam \& Grönlund, 2011).

This research identified cellphone ownership as a major determinant of cellphone use during marine fishing which is supported in several studies. For instance, Freeman \& Mubichi (2017), Okello et al. (2014) has submitted device ownership as an important factor in the use of ICT for agriculture and market information. Another study in Hungary Mezei, Benyi, and Muller (2007) also explored association in mobile ownership and regular use among school children. In fact, ownership of device can guarantee instant access to services if the user has skill in using device and other facilities, such as balance, power supply, etc. 


\section{Practical implications}

Warm tropical climate accompanied by high rainfall and flow of abundant nutrients from the land has created the coastal and marine environment of Bangladesh as world's richest ecosystems with high productivity (Hossain, 2001; Islam, 2003 in Shamsuzzaman et al., 2017). Despite the presence of huge marine resources, marine fishing in Bangladesh is predominantly performed through non-mechanised boats. According to DoF (2016), marine fish stock in the country is captured and harvested through a limited number of commercial trawlers (247 trawlers), 32,859 motor driven boats and 34,810 non-motor driven artisanal boats. This low mechanisation posed several challenges, such as lower amount marine catch, over exploitation of shallow marine area, inability to usurp the potential of the commercial fishing zone, and loss of life and resources in the sea. Efficiency of marine fishing and loss of lives and resources can be minimised by applying cell phone. The mobile phone could help fishermen with safety information and effective fishing through providing real-time information on potential fishing zones (Amrita \& Karthickumar, 2016). However, use of cell phone for marine fishing depends upon both modifiable and non-modifiable factors. Two major modifiable factors identified in this research are availability of cell phone network and ownership of cellphone device. Hence, Policymakers should take immediate initiatives to develop the mobile phone network infrastructure to amplify the mobile phone network coverage in the potential marine fishing zones of the country. Policies also need to identify pathways to increase cellphone ownership among the fishers as cellphone ownership is a key driver of cellphone use during marine fishing.

Future studies should evaluate the ways of innovate application of cell phone for better fishing and providing real-time information on the dynamic ocean environment in a cost-effective way. Spatial research is also necessary to explore other socioeconomic and demographic factors influence the use of cell phone during marine fishing.

\section{Limitations of the study}

This study embraces several limitations, such as fisherman's use of cellphone may vary significantly based on geographical location and socioeconomic status of the fishermen. The geographical coverage of this study is very limited, which may fail to capture the real situation due to failure of considering spatial variability. Socioeconomic factors supposed to influence the fishermen's use of cellphone are not limited as this study perceived. So, consideration of more factors could portray a more vivid picture. Last but not least, this study measured fisher's situation and their use

of cell phone based on respondent's opinion. However, direct observation of the real situation during marine fishing may provide a more precise scenario. 


\section{Conclusions}

The application of cell phone in the marine fishing sector can cater numerous benefits related to income, safety, and security. This study attempts to explain the factors that influence the use of cell phone during marine fishing by the sea fishers and found income from sea fishing, information need, network availability, and ownership of cell phone as significantly influential factors. Thus, for the additional use cell phone during marine fishing, the concerned authorities intend to enhance income, security and risk reduction in sea fishers using cell phone-based services, should shed light on the development of cell phone network in potential fishing zones of Bangladesh. Moreover, they also need to consider the supply of cell phones in affordable price. The findings of this study provide an applied guideline for the increased use of cell phone during marine fishing in developing countries. In addition, this study also creates an opportunity for cell phone-based fishing technology developers and information service providers to gain a better understanding of the end users, which in turn will develop their capacity to face the challenges in designing and implementing successful cell phone-based services.

\section{Acknowledgment}

This research was supported by a Patuakhali Science and Technology University research grant. The authors thank the survey participants for their contribution to this research.

\section{References}

Akinola A.A. (2017), Influence of socio-economic factors on farmers' use of mobile phones for agricultural information in Nigeria. Library Philosophy and Practice (e-journal). 1688. Available at: https://core.ac.uk/download/pdf/188123811.pdf

Alam G.M.M., Alam K., Mustaq S., Khatun M.N. and Mamun M.S.A.K. 2018. Influence of socio-demographic factors on mobile phone adoption in rural Bangladesh: Policy implications. Information Development, 35(5): 739-748. doi: https://doi.org/10.1177/0266666918792040

Altabatabaie K.F. 2018. Adoption and appropriation of mobile phone on the Iraqi society. International Journal of Scientific \& Technology Research 7(7):14-18.

Amrita C.M. and Karthickumar P. 2016. Need for mobile application in fishing. International Journal of Science, Environment and Technology, 5(5): 2818 - 2822.

Asif A.S., Uddin M.N., Dev, D.S. and Miah M.A.M. 2017. Factors affecting mobile phone usage by the farmers in receiving information on vegetable cultivation in Bangladesh. Journal of Agricultural Informatics, 8(2): 33-43.

Barrantes S.A., Rodrlguez M. and Pérez R. 2009. Information management and communication in emergencies and disasters: manual for disaster response 
teams. Pan American Health Organisation. Washington, D. C. Available at: www.paho.org/disasters/index.php?option=com_docman\&task=doc...gid

Boadi R.A., Boateng R., Hinson R. and Opoku, R.A. 2007. Preliminary insights into $\mathrm{m}$-commerce adoption in Ghana. Information Development, 23 (4): 253-265.

Daoud Jamal I. 2017. Multicollinearity and regression analysis. J. Phys.: Conf. Ser. 949 012009

DoF. 2016. National fish week, compendium (In Bengali). Department of Fisheries, Ministry of Fisheries and Livestock, Government of Bangladesh, Dhaka

Dufty N. 2014. A review of the value of social media in countrywide disaster risk reduction public awareness strategies. Input paper, The United Nations Office for Disaster Risk Reduction.

Ericson. 2012. Mobile weather service improves safety of fishermen in Uganda. Available at: https://www.ericsson.com/news/120510_mobile_weather_service_improves_s afety_of_fishermen_in_uganda_244159019_c ,

FEMA. 2014. Communicating in an emergency. Available at: https://training.fema.gov/emiweb/is/is242b/student\%20manual/sm_03.pdf

Financial Express. 2016, November 26. Pirates abducted fishermen from Bay of Bengal. Available at: http://www.thefinancialexpress-bd.com/2016/03/05/19516

Freeman K. and Mubichi F. 2017. ICT use by smallholder farmers in rural Mozambique: a case study of two villages in Central Mozambique. Journal of Rural Social Sciences, 32(2): 1-19. Available at: https://egrove.olemiss.edu/jrss/vol32/iss2/1

Govindaraju P. and Mabel M. 2010. The status of information and communication technology in a coastal village: A case study. International Journal of Education and Development using ICT, 6 (1):129-135.

Gujrati D.N., Porten D.C. and Gunasekar S. 2012. Basic Econometrics (5th ed.). India: Mcgraw Hill.

Hosmer D. and Lemeshow S. 2000. Applied logistic regression (2nd ed.). New York: John Willy and Sons.

Hummayan N.M. and Barua S. 2016. Present status of commercially important fish in trawl catch of Bay of Bengal. Proceedings of National Fisheries Week, Dhaka: Ministry of Fisheries and Livestock, Bangladesh.

Hussain M.G. and Hoq M.E. (Eds.) 2010. Sustainable management of fisheries resources of the Bay of Bengal- Compilation of national and regional workshop reports. Support to Sustainable Management of the BOBLME Project, Bangladesh Fisheries Research Institute: SBOBLMEP Pub./Rep. 2.

Islam M.S. and Grönlaund A. 2011. Factors Influencing the Adoption of Mobile Phones among the Farmers in Bangladesh: Theories and Practices. International Journal on Advances in ICT for Emerging Regions, 4(1): 4- 14. 
Jensen R, 2007. The digital provide information technology, market performance, and welfare in the south Indian fisheries sector. The Quarterly Journal of Economics,122(3): 879-924.

Khan M.G. 2010. Bangladesh coastal and marine fisheries, and environment. In: Sustainable Management of Fisheries Resources of the Bay of Bengal by M.G. Hussain and M.E. Hoq (Eds.), Support to BOBLME Project, Bangladesh: Bangladesh Fisheries Research Institute.

Kissling E., Allison E.H., Seeley J.A., Russell H., Bechmann M., Musgrave S.D. and Heck S. 2005. Fisher folk are among those most at risk to HIV: a cross-country comparison of estimated prevalence and numbers infected among groups at risk. AIDS, 19: 1939-1945.

Lincoln J.M., Hudson D.S., Conway G.A. and Pescatore R. (Eds.) 2002. Proceedings of the International Fishing Industry Safety and Health conference. Woods Hole, Massachusetts: Department of Health and Human Services.

Matuha M. 2015. Mobile phone use in Ugandan aquaculture: farmer experiences and aspirations. MSc Thesis. Graduate Faculty of Auburn University, Auburn University, Alabama.

Mezei G., Benyi M. and Muller A. 2007. Mobile phone ownership and use among school children in three Hungarian cities. Bioelectromagnetics, 28(4):309-315. Doi: 10.1002/bem.20270

Mobile Networking: Definition, Components \& Comparison. 2018, August 8. Available at: https://study.com/academy/lesson/mobile-networking-definitioncomponents-comparison.html

Nishikura M. 2010. Resilient Bangladesh: fishermen cope with rough seas. Available at: https://ourworld.unu.edu/en/resilient-bangladesh-fishermen-cope-withrough-seas,

Njuguna I.M., Munyua C.N. and Makal S.K. 2015. Influence of demographic characteristics on adoption of improved potato varieties by smallholder farmers in Mumberes Division, Baringo County, Kenya. Journal of Agricultural Extension and Rural Development, 7(4), 114-121. Doi: 10.5897/JAERD2014.0607

Nyamba S.Y. and Mlozi M.R.S. 2012. Factors influencing the use of mobile phone in communicating agricultural information: a case of Kilolo district, Iringa, Tanzania. International Journal of Information and Communication Technology Research, 2(7): 558-563.

Obong R., Mugonola B. and Phillips D.P. 2017. Determinants of mobile phones usage in sweet potato vine business in Gulu district northern Uganda. African Journal of Agricultural Research, 13(21): 1071-1079.

Okello J., Kirui O., Gitonga Z., Njiraini G. and Nzuma J. 2014. Determinants of awareness and use of ICT-based Market Information Services in developing 
country agriculture: the case of smallholder farmers in Kenya. Quarterly Journal of International Agriculture, 52(3): 263-282.

Pandey S. 2015. Pirates of the Bay of Bengal.

http://www.aljazeera.com/indepth/features/2015/09/pirates-bay-bengal150914123258304.html

Qualicomm. 2016. Fisher Friend: helping to save lives and improve incomes of fishermen. Available at:https://www.qualcomm.com/media/documents/files/india-fisher-friend.pdf,

Rider D. 2015. "Pirates" kill fisherman, injure 35. Available at: http://www.marsecreview.com/2015/10/pirates-kill-fisherman-injure-35/

Salas S., Bjørkan M., Bobadilla F. and Cabrera M.A. 2011. Addressing vulnerability: coping strategies of fishing communities in Yucatan, Mexico. In: Poverty mosaics: realities and prospects in small-scale fisheries by S. Jentoft and A. Eide (Eds.). Dordrecht: Springer.

Seshan V.E., Gönen M., Begg C.B. 2013. Comparing ROC curve derived from regression models. Stat. Med., 32(9): 1483-1493.

Shamsuzzaman M.S., Islam M.M., Tania N.J., Al-Mamun M.A., Barman P.P. and Xu X. 2017. Fisheries resources of Bangladesh: Present status and future direction. Aquaculture and Fisheries, 2(4): 145-156, doi:

https://doi.org/10.1016/j.aaf.2017.03.006

Sikundla T., Mushunje A., Akinyemi B.E., Sandra Ricart Casadevall (Reviewing editor) .2018. Socioeconomic drivers of mobile phone adoption for marketing among smallholder irrigation farmers in South Africa, Cogent Social Sciences, 4(1), doi: 10.1080/23311886.2018.1505415

Singh D., Kimbahune S. and Singh V.V. 2017. Strategy for deep sea communication for safe fisheries - mKRISHI fisheries, a case study. Journal of ICT Standardisation, 4(3): 199-212, doi: 10.13052/jicts2245-800X.432

Smith M.E. 1998. Fisheries risk in modern context. Maritime Anthropological Studies, 1, $29-48$.

Tirkaso W.T. and Hess S. 2015. The role of ICT expenditure for cash crop production and income generation in Southern Ethiopia. EJISDC, 71(2): 1-14.

Urassa N.S. and Mvina Z.S.K. 2016. Determinants of the use of cell phones in access to beef cattle market information for smallholders in Mpwapwa district, Tanzania. Huria: Journal of the Open University of Tanzania, 22(1). https://www.ajol.info/index.php/huria/issue/view/15494 